\title{
КІБЕРАКМЕОЛОГІЧНІ ЗАСОБИ ЕКСПРЕС-АНАЛІЗУ І МОНІТОРИНГУ БІОЛОГІЧНИХ ОБ'ЄКТІВ НА ОСНОВІ ПРОЕКТУВАННЯ МЕДИКО- БІОЛОГІЧНИХ ІНФОРМАЦІЙНИХ СИСТЕМ
}

\author{
В. М. Антонов, Ю. В. Антонова-Рафрі \\ Українська академія акмеологічних наук \\ Національний технічний університет України "КП।"
}

\begin{abstract}
Розглянуто питання теорії і практики кіберакмеологічного та кібербіхевіористичного підходів до управління високопродуктивними когнітологічними автоматизованими робочими місцями (АРМ), що полягає у широкому використанні комп'ютерних інформаційних технологій в процесі прийняття управлінських рішень на принципах синергетичного, акмеологічного й креативного управління. Розроблена концепція, принципи та вимоги до побудови АРМ з метою їх проектування на основі відповідної технології. Визначена класифікація АРМ.
\end{abstract}

Ключові слова: кібернетика, акмеологія, інформаційні технології, АРМ.

\section{КИБЕРАКМЕОЛОГИЧЕСКИЕ СРЕДСТВА ЕКСПРЕСС-АНАЛИЗА И МОНИТОРИНГА БИОЛОГИЧЕСКИХ ОБЪЕКТОВ НА ОСНОВЕ ПРОЕКТИРОВАНИЯ МЕДИКО-БИОЛОГИЧЕСКИХ ИНФОРМАЦИОННЫХ СИСТЕM}

\author{
В. М. Антонов, Ю. В. Антонова-Рафии \\ Украинская академия акмеологических наук \\ Национальный технический университет Украини "КПИ"
}

\begin{abstract}
Статья посвящена рассмотрению вопросов теории и практики киберакмеологичного и кибербихевиористичного подхода к управлению высокопроизводительными когнитологическими автоматизированными рабочими местами (AРM), который основан на широком использовании компьютерных информационных технологий в процессе принятия управленческих решений на принципах синергетического, акмеологического и креативного управления. Разработана концепция, принципы и требования к построению АРМ с целью их проектирования на основе соответствующей технологии. Разработана классификация АРМ.
\end{abstract}

Ключевые слова: кибернетика, акмеология, информационные технологии, APM.

\section{CYBERACMEOLOGIC FACILITIES OF EXPRESS - ANALYSYS AND MONITORING OF BIOLOGICAL OBJECTS ON THE BASIS OF PROJECTING OF MEDICAL-BIOLOGICAL INFORMATION SYSTEMS}

\section{M. Antonov, Yu. V. Antonova-Rafi}

Ukrainian Academy of Acmeoiogic Sciences National Technicai University of Ukraine "KPl"

\footnotetext{
The article is devoted to the development of theory and practice of cyberacmeologic and cyberbehaviour approach to control high- rate cognitology (knowledge) Automated Work Place (AWP) on the basis of wide use of computer information technologies in the process to control decisions by the ways of synergetic, acmeologic and creative control. There were worked out the conception, principles and requirements for construction (building) AWP in order to project on the bas's of corresponding technology. It was defined the classification of AWP.
}

Key words: cybernetics, acmeology, information technologies, AWP. 
Вступ. Кіберакмеологія - це наука про технологічне моделювання розвитку та удосконалення творчої індивідуальності людини (особистості); методологія проектування нових знань про людину та досягнення бажаного результату (успіху, влади, здоров'я, багатства тощо), яка включає технологічні моделі і методи створення архітектоніки (гармонійне поєднання частин у єдине ціле) для креативного саморозвитку особистості на еволюційному шляху творчої зрілості та впровадженні математичних акме-систем, що базується на основних принципах таких наук як кібернетика, акмеологія, синергетика, біхевіоризм, когнітологія тощо.

Концепція кіберакмеології полягає у теоретичному і практичному (прикладному) моделюванні талантів та здібностей особистості на основі сучасних інформаційних технологій (IT) - за рахунок методології досягнення акме-точок Людини у різних областях та ситуаціях, та реалізація побудованої моделі на основі філо- і онтогенезу у вигляді кіберакмеологічної інформаційної системи (IC).

Принципи кіберакмеології полягають у наступному: структурування власного суб'єктивного досвіду на основі СIT, формування автокреативності, конструювання внутрішнього світу людини, комунікації та людського спілкування, інтелектуальної синергетичності особистості, магнітологічної акмеологічності людства, креативної біхевіористичності особистості, програмування швидкого інтелектного навчання, проектування: стану узгодженості (конгруентності) 3 собою (з довкіллям); внутрішньої узгодженості та гармонії тощо; потрібного емоційного стану; потрібного нейрофізіологічного стану; екології взаємовідносин і т. ін., результативності креативного розміркування, сенергетичності та динамічності, інтерактивності та ітеративності, багатосередовищності реалізації, формування індивідуальних карт світу за рахунок людських фільтрів, альтернативньості та узгодженості, позитивності та конструктивності у досягненні мети, когнітологічної тристоронності (трикреативності) та збалансованості життєдіяльності людини (інтуїція, свідомість, підсвідомість), креативної ресурсності та потенційної енергії і можливостей, моделювання успішної синергетично-креативної особистості, креативності саморозвитку, екологічності та гармонії з довкіллям, когерентності (зв'язності) моделювання.

Мета дослідження - полягає у застосуванні нової технології - кіберакмеології експрес-аналізу і моніторингу біологічних об'єктів за допомогою АРМ у кібернетично-акмеологічних медико-біологічних інформаційних системах (КАМБІС) [1 - 4].
Методи кіберакмеології мають широке застосування при проектуванні АРМ або людино-комп'ютерних комплексів (Л-КК), чи програмно-технологічних систем. Класифікація відповідних АРМ, що створюються, представлена таким чином: фактологічні, кіберакмеологічні та гібридні. Фактологічні поділяють на функціонально-спеціалізовані (ФС), наукові, підтримки прийняття рішень, навчальні, проектувальні. ФС складаються з колективного користування (підготовчо-оброблювальні, колективно-фукціональні, ситуаційно-дорадчі) та індивідуальних (персонально-спеціалізованих, індивідуально-клавішних, сенсорних та дослідницьких). Кіберакмеологічні АРМ включають креативні, інтелектуальні (когнітологічні, експертні), кібербіхевіористичні, акмеологічні, синергетичні, генетичні, нечіткі, паралельні, розподілені. Гібридні - це: кіберакмеологічно-когнітологічні, когнітологічно-синергетичні, когнітологічно-синергетичні акме - АРМ, креативні акме - АРМ, інтелектно-дистанційні, генетично-кіберакмеологічні, нечіткі кіберакмеологічні, інтелектуально-інтерактивні мережево - кластерні.

Кіберакмеологічні АРМ - це людино-комп'ютерний комплекс (ЛКК) для моделювання талантів та здібностей особистості за рахунок досягнення акметочок людини у різних областях та ситуаціях. Це АРМ 3 особливостями ресурсного моделювання можливостей особистості, розвитку та удосконалення іiї творчої індивідуальності на основі відповідних психофізіологічних законів життя людини.

Кіберакмеологічні АРМ аналізуються таким чином. Креативні АРМ - це АРМ 3 домінантно-творчою характерною особливістю. Інтелектуальні (когнітологічні) - це АРМ когнітологічно-експертного характеру, побудовані на базах комп'ютерних знань, мета-знань та експертно-аналітичних методах. Кібербіхевіористичні АРМ - це АРМ, які враховують поведінкові (психосоматичні) особливості людини та іiі фільтри сприйняття довкілля (зовнішнього і внутрішнього). Акмеологічні АРМ - орієнтовані на аналіз та синтез творчо «вершинних» (акме-) досягнень особистості. Акмеологічність АРМ - це такий чинник, що дозволяє враховувати індивідуальні особливості ОПР при вирішенні його функціональних задач. Синергетичні АРМ - це АРМ, побудовані за технологією отримання кінцевого результату (сигналу, ефекту), що більше ніж просто сума вхідних потоків (сигналів, дій). Генетичні АРМ - це АРМ, що реалізовані на основі генетичних алгоритмів і операторів для вирішення творчо-дослідницьких задач. Нечіткі - це AРM побудовані на fuzzy - технології та 
розмитих множинах. Паралельні - це АРМ, в основі яких реалізована GRADE -технологія. Розподілені це APM, що проектуються на основі grid - технології [5-12].

Гібридні АРМ - розробляються у межах одного цілісного об'єкта та є комплексом об'єктно-орієнтованих інтегрованих АРМ різних не програмуючих фахівців у межах однієї фірми, корпорації, організації, підприємства, виробництва тощо. Аналізуються такі гібридні АРМ. Кіберакмеологічні магнітологічні (КК) АРМ - це гібридні АРМ кіберакмеологічно-когнітивного характеру. Когнітологічно-синергетичні (КС) АРМ - це творчо-орієнтовані інтегративно-динамічні та генетично-ефективні АРМ з когнітологічно-синергетичною домінантою. Когнітологічно-синергетичні акме (КСА) - АРМ - це комплексні АРМ 3 характерними особливостями технологій: когнітологічної, синергетичної, акмеологічної.

Креативні акме (КА) АРМ - це АРМ, що реалізовані на визначення творчих «дахових», вершинних (акме) точок людини. Інтелектуально-дистанційні (ІД) АРМ - орієнтовані на підтримку користувача при його роботі і навчанні у мережі. Генетично-кіберакмеологічні (ГК) АРМ - використовують апарат генетичних алгоритмів і операторів для технологічного моделювання розвитку та удосконалення творчої індивідуальності людини. Нечіткі-кіберакмеологічні (НК) АРМ - використовують інструментарій нечіткої логіки та теорії розмитих множин для проектування нових знань стосовно технології досягнення бажаного результату. Інтелектуально-інтерактивні мережево-кластерні (II MК) АРМ - призначені для діалогово-креативного вирішення проблем користувача на мережах з використанням GRADE, grid-технологій. Вони побудовані на основі баз знань та метазнань, що містять набір рішень та методи моделювання альтернативних пропозицій у випадку їх відсутності. Особливістю цих АРМ є локально-персоніфіковані та колективно-розподілені процеси обробки даних, знань, мета-знань.

Особливий клас АРМ - інтегровані автоматизовані системи, що будуються на основі синергетичного принципу з управлінням шляхом інтегрованої інтелектуальної автоматизованої системи з широким використанням сучасних і перспективних інформаційно-комп'ютерних технологій (клієнт-сервер технологія, гіпер-медіа зв'язки, інтелектуальні ФС-АРМ, ситуаційно-дорадчі АРМ, системи підтримки прийняття рішень - СI IIIP синергетична технологія, корпоративно-офісна технологія, віртуальна технологія, інтелектуальна робототехніка, кіберакмеологія тощо).
Методологія проектування розглянутих АРМ, на думку авторів, полягає у наступному:

• визначення концепції та принципів;

- формулювання загальних та спеціалізованих вимог, а також умов створення;

- розробка норм і правил класифікації;

- визначення стадій створення та життєвого циклу, а також фахівців, що беруть участь у проектуванні;

- опис складу і змісту робіт при проектуванні (аналіз, дослідження, синтез, модифікація тощо);

- організація і технологія розробки, перевірки, впровадження, контролінгу, моніторингу, експлуатації, удосконалення, захисту, знищення тощо;

- забезпечення відповідних властивостей (науковотехнічного рівня, економічної ефективності, адаптивності і т. ін.);

- розробка організаційного забезпечення (зміст, інтегрованість, зв'язки, нормативно-правова база, процедури та цикли управління, ергономічне забезпечення тощо);

- розробка інформаційного, технологічного, технічного, програмного, математичного, кадрового, правового, лінгвістичного забезпечення;

- визначення умов розробки на існуючих або нових об'єктах;

- визначення джерел фінансування;

- розробка мережево-кластерних та дистанційних особливостей;

- розробка веб-дизайну та веб-мастерінгу;

- розробка необхідних е-підручників.

На основі сформульованого підходу стосовно методики проектування АРМ у статті аналізується технологія створення кіберакмеологічних програмних, людино-комп'ютерних комплексів та IC на основі кібербіхевіористичного методу (технології).

Вперше запроваджено нове поняття - кіберакмеологічні IC та кіберакмеологічні медико-біологічні IC (КАМБІС). Мета роботи кіберакмеологічної IC видати користувачеві конкретні поради та рекомендації за певним запитом. Це можуть бути рекомендації щодо дій особи в конкретній ситуації, або загальні поради щодо покращення стану здоров'я, експрес-аналізу та моніторингу стану біологічних об'єктів, набуття бажаних особистих якостей тощо. Інформація про особу має бути одержана інформаційною системою в результаті аналізу результатів тестування та діагностики. Рекомендації видаються 3 урахуванням всіх доступних системі відомостей про конкретного користувача.

Одним з основних принципів роботи кіберакмеологічної IC є кібербіхевіористичний метод. Цей метод 
допомагає динамічно керувати роботою системи за допомогою інформації, отриманої від користувача. Це дає можливість постійно коригувати роботу системи, враховуючи зміни в поведінці особи, та забезпечує можливість постійної модернізації системи.

Сутність кібербіхевіористичного методу полягає в тому, що людина, надаючи кіберакмеологічній системі необхідну для аналізу інформацію та отримуючи на виході рекомендації, робить цей процес обміну інформацією динамічним. Це означає, що рекомендації, які система надає особі, впливають на поведінку останньої, а людина, надаючи системі нові дані про себе, змінює рекомендації системи, тобто процес $є$ двостороннім.

Кіберакмеологічна медико-біологічна інформаційна система (КАМБІС) надає особі методи розв'язання конкретної задачі чи рекомендації щодо досягнення акме-вершин. Особа може втілити рекомендації в життя, після чого її поведінка зміниться, може не втілювати, і їі поведінка залишиться такою ж, а може змінити власну поведінку не під дією рекомендацій кіберакмеологічної системи, а під дією факторів довкілля, психологічних факторів тощо. Крім того, особа може змінити свої цільові установки (наприклад, замість професійного успіху забажати покращення стану здоров'я). Завдання кібербіхевіористичного методу - визначити, чи відбулись у поведінці особи зміни, i, якщо так, надати їй нові рекомендації. При цьому слід враховувати, мали зміни конструктивний або деструктивний характер. На практиці це можна визначити, порівнявши результати тестування особи, отримані раніше, з результатами тестування, отриманими через певний час після надання рекомендацій. Для цього слід повернутися на перший етап кібербіхевіористичного дослідження, тобто користувач знову надає інформаційній системі особисті дані у вигляді повторного тестування.

Кібербіхевіористичний метод взаємодії кіберакмеологічної системи та користувача дає можливість особі отримати актуальні рекомендації, які враховуватимуть найменші зміни в ії поведінці, а інформаційній системі - оперувати найточнішими даними та фіксувати досягнення людиною акме-вершин. Цей метод робить кіберакмеологічну систему гнучкою та універсальною.

Вперше розроблені нові концептуальні аспекти проектування синергетично-когнітологічних АРМ медико-біологічного спеціального призначення.

Перелічимо основні принципи стосовно концепції кібернетично-когнітологічної синергетики: мультистабільність; відкритість, динамічність, антагоні- стичність, кластерність (доменність), характеристичність, еволюційність, мозаїчність, прогнозність, континуальність, асимптотичність, рецепторність, кон'юнктурність, конфліктність, домінантність, стаціонарнонормірувальність, дискретність, індивідуальність, цінністість, творчо-розумовість, інтелектність, інтегративність, самоорганізації правил тощо.

Авторами досліджуються нові синергетично-когнітологічні акме-АРМ. Синергетично-когнітологічні акме-АРМ проектується 3 метою дослідження складних інтегрованих процесів, що мають місце у суперскладних менеджерських дисипативно-інтелектних системах прогнозного (антиципативного) напрямку, які характеризуються інтенсивним (множинно-дискретним або континуальним) обміном даними, знаннями, мета-знаннями між своїми компонентами і довкіллям та які внаслідок свого ефективного функціонування мають змогу: працювати стабільно до моменту надходження (зовні) або накопичення (внутрішньо) критичної енергії (інформації, даних, знань, мета-знань); мати своїм результатом когнітологічне упорядкування, самоорганізацію, прогресивну еволюцію та зменшення ентропії, а також самоудосконалюватися або саморуйнуватися внаслідок розбалансування своїх компонентів (підсистем, модулів, інгредієнтів, доменів, кластерів, інформаційних елементів, програмно-технічних та функціонально-технологічних сутностей тощо).

Наголошена концепція створення акме-АРМ «вимагає» від них базуватися при їх впровадженні на таких принципах: акмеологічність, синергетичність, когнітологічність, мультистабільність, генетичність (динамічність, відкритість, успадкованість), антагоністичність (конфліктність), кластерність, еволюційність, мозаїчність (доменність), прогнозність, континуальність, кон'юнктурність, «творчо-розумовість» тощо.

Вводиться нове поняття синергетично-когнітологічної акмеології і обгрунтовується цей підхід концептуально і принципово. Запропонований підхід до створення синергетичних магнітологічних АРМ на основі акмеологічних принципів дозволить проектувальникам і користувачам сучасних акме-АРМ проектувати і використовувати перспективні комп'ютерноінформаційні і телекомунікаційні технології для опису та аналізу суперскладних об'єктів з метою прийняття і підтримки ефективних управлінських рішень ОПР.

При модифікації К-АРМ з позиції синергетичного принципу і поняття акте можна побудувати спецархітектуру креативного мінімаксного розвитку системи за такими рівнями: ресурсним, функціональним, 
технічним, технологічним, алгоритмічним, математичним, креативним, філологічним, кіберакмеологічним тощо.

Ресурсний рівень самокреативного К-АРМ вміщує інтелектуальні властивості системи і задачі, що ще не вирішувалися К-АРМ (нові задачі).

Функціональний модуль (рівень) - характеризується специфічними задачами і функціями, що реалізується в К-АРМ (автономність системи).

Технічний рівень - обумовлений тими технічними засобами автоматизації, що застосовуються при створенні або розвитку К-АРМ.

Технологічний рівень - забезпечує проектувальників системи інструментарієм стосовно використання сучасних інформаційно-комунікаційних технологій стосовно створення К-АРМ.

Алгоритмічний рівень - це рівень, де зберігаються і накопичуються алгоритми обробки, перетворення даних, знань та мета-знань; алгоритми керування системою; алгоритми створення архівів; алгоритми захисту тощо.

Математичний рівень - це множина моделей та методів вирішення завдань К-АРМ, реалізації функцій ОПР, НФ тощо.

Креативний рівень - забезпечує інтелектні можливості К-АРМ.

Філологічний рівень - характеризується можливістю реалізації в К-АРМ таких здібностей, які об'єднуються ключовим виразом "образне К-АРМ", т. т. можливість К-АРМ розуміти природну українську мову, "розмовляти" нею, синтезувати нові словоформи тощо.

Кіберакмеологічний рівень - дає можливість проектувати такі К-АРМ, що найбільш комфортно відповідають біхевіористичним можливостям людини-користувача К-АРМ.

Когнітологічний принцип створення К-АРМ реалізує такий підхід, при якому АРМ, які проектуються, базуються на основі роботи з базами даних, базами знань та мета-знань, реалізуючи при цьому креативний (творчий) рівень обробки інформації з метою генерації нового знання (синтезу знань) на основі використання вже відомих знань (загальних або індивідуальних).

Для цього в архітектурі проектованих К-АРМ створюється відповідний пристрій логічного виводу, тобто "синтезатор" даних і знань.

Критеріальним показником рівня інтелекту К-АРМ, що розробляється, є його здатність використовувати накопичені знання для синтезу нових знань та для виводу відповідних знань.
Таким чином, планується, що головною функцією розроблюваних АРМ буде функція креативності, тобто творча функція.

Креативні акме-АРМ повинні допомогти креативній особистості, яка постійно перебуває у екстремальних ситуаціях при обробці великої кількості креативної інформації, перебороти стан психологічної невпевненості, який виникає в умовах прийняття рішень у невизначених або слабо визначених ситуаціях.

Модель має назву КОМОДИНА - комп'ютерна модель дистанційного навчання, - і забезпечує реалізацію таких елементів: статична парадигматика знань, динамічна інформація, синхронна парадигматика матеріальних форм, динамічна синтагматика (комбінаторика) матеріальних форм (звукотипів, морфем, слів тощо). Перелічені елементи попарно зв'язані двома вимірами - дихотоміями: зміст - форма, статика - динаміка.

Модель також призначена для дослідження процесів аналізу і синтезу тексту (змісту дистанційних процесів) у мозку людини з метою ефективності засвоєння матеріалу.

Модель базується на парадигмах лінгвістичного моделювання: епістемологічт, онтологічні; гіпотетичного моделювання; відтворюючих моделях: лінгвістичні, інженерно-лінгвістичні, лінгво-дидактичні.

У запропонованій моделі нової освітньої технології для особистості інтегровані модулі мають такі функціональні особливості.

Рефлексивний модуль - це модуль, який оцінює здатність людини стати у позицію спостерігача, дослідника, контролера стосовно до свого тіла, дій, думок (міркувань, умозаключень), поведінки, психіки, світогляду (менталітету) тощо.

Модуль аналізу накопиченої тематичної інформації - це модуль, що аналізує підготовлену педагогом тематично-цільову інформацію за допомогою відповідних методів обробки інформації та математичних моделей формалізації конкретної інформації.

Модуль синтезу інформації - це модуль динамічної генерації відповідних тематичних баз даних, знань та мета-знань, який на основі необхідних комп'ютерних засобів та відповідних когнітологічних алгоритмів перетворює дані та комп'ютерні знання у конкретні навчальні теми за визначеними програмами.

Модуль вибору біхевіористичної моделі - це модуль аналізу існуючих чи перспективних біхевіорістичних (поведінкових) моделей людини та "прив'язки" їх до відповідних груп учнів, які були визначені педагогом (чи його психологічно-аналітичною групою) на етапі попереднього аналізу. 
Соціонічний модуль - це модуль аналізу та розподілу учнів на раціонально/ірраціональні психологічні типи (групи) за відповідною ментологічною методикою.

Модуль ранжованого тестування призначений для визначення груп учнів відповідно до їх розумових здібностей та побажань.

Модуль соціонічно-ранжованого групування - використовується на підсумковому етапі класифікації учнів за методикою їх розподілу на гібридні групи 3 урахуванням їх психологічно-розумових здібностей, побажань та стану здоров'я.

Модуль аналізу результатів взаємодії - це модуль, який підсумовує ступінь (кількість і якість) ефективності засвоєння і використання користувачами відповідних знань та видає результати раціональності використання педагогом відповідних дидактичних принципів, педагогічних методів, прийомів, засобів, методик та технологій.

Модуль прогнозування та передбачення - призначений для "планування" перспективних нових аспектів діяльності педагога у межах задекларованої освітньої технології, включаючи нові алгоритми, моделі, методи та інформаційно-організаційні, програмно-технічні, лінгвістично-семіотичні, правові тощо підходи та забезпечення.

Модуль удосконалення запропонованої моделі використовується для вироблення (генерації) нових пропозицій щодо зміни, модифікації параметрів (характеристик) працюючої технологічної моделі на основі когнітологічного підходу.

Отже, побудоване АРМ з дистанційної освіти має всі ознаки креативного (творчого) АРМ, що надає можливість особистості у процесі дистанційної освіти використовувати головні функції інтелекту: розуміння, синтез та аналіз знань, накопичення, зберігання, передача як знань, так і мета-знань.

Головне у такому АРМ - це можливість використання отриманих знань для генерування нових знань, тобто синтезу знань на базі використання як „негативної", так і „позитивної" інформації, яка відкриває нові закономірності та зв'язки і налаштовує того, кого навчають, на „континуум думки планетарних масштабів".

Генетичні кіберакмеологічні АРМ - особистості (ГКА АРМ-М) - це засоби обчислення задач оптимізації, в основі яких лежать еволюційні принципи, тобто, зазвичай є деяка функція від декількох змінних (цільова функція), для якої потрібно знайти максимум (мінімум).

Параметри функції - це генетичний матеріал - гени. А сукупність генів, як відомо, утворюють хромосому (набір параметрів), яка в свою чергу і характеризує будь-яку особистість.

Таким чином, підставляючи параметри у цільову функцію (ЦФ) - отримаємо якесь значення.

Генетичні алгоритми (ГА), на основі яких функціонують ГКА АРМ-М, працюють 3 множиною варіантів (способів) проектування ГКА АРМ-М, які у подальшому можна оцінити специфікацією з метою прийняття рішення, який варіант краще (ефективніше) . Варіанти «перемішуються» між собою за допомогою генетичних операторів (ГО), а вибір найкращих варіантів здійснюється у відповідності до ефективної стратегії. Потім сформовані варіанти знову оцінюються ГА, і знову обчислюються найкращі для наступного «перемішування» і вибору найефективніших і т. ін.

Процес продовжується до тих пір, поки не буде спроектований такий ГКА АРМ, гени-параметри якого будуть являти собою оптимістичний набір параметрів, при яких ЦФ буде наближатися до мінімуму або дорівнювати йому.

Але процес може бути припинено у випадку «виходжування» варіантів, тобто, практично відсутнього варіанта реалізації ГКА АРМ. Це називається «достроковою сходимістю».

Генетичні алгоритми (ГА) будуються на основі генетичних операторів (ГО), що реалізують інструментарій успадкування і зміни варіантів проектування ГКА АРМ.

Запропоновані і реалізовані нечіткі кіберакмеологічні АРМ (НКА-АРМ).

НКА - АРМ будуються на принципах нечіткої (fuzzy) логіки та теорії розмитих множин (fuzzy sets), що $з$ успіхом можна використовувати для моделювання механізму логічних виводів людини як не computer'a, тобто розумної істоти, яка 3 легкістю, без зусиль (на рівні підсвідомості та несвідомого знання) - оперує якісними, а не кількісними оцінками на основі правил продукції.

Висновки. Запропонований підхід надає нові можливості до аналізу існуючих IC та проектування нових на основі розроблених АРМ та інноваційної технології - кіберакмеології. 


\section{Література}

1. Антонов В. М. Інтелектуально-математичний менеджмент: кіберакмеологічні концепція / В. М. Антонов. - К. : KHT. - 2007. - $528 \mathrm{c}$.

2. Антонов В. М. Інтелектуальні АРМ / В. М. Антонов. - К. : ВПЦ «Київський університет». - 2000. - 158 с.

3. Антонов В. М. Кібернетична акмеологія: теорія та практика моделювання, акселерації та розвитку людини / В. М. Антонов, Ю. В. Антонова-Рафі. - Київ: КНТ. - 2011. - $280 \mathrm{c}$.

4. Антонов В. М. Кібернетична акмеологія: технологія розвитку та удосконалення Людини: монографія / В. М. Антонов. - К. : ВПЦ «Київский ун-т», 2011. - 290 с.

5. Бабенко Л. П. Основи програмної інженерії / Л. П. Бабенко, Е. М. Лавріщева. - К. : Знання, 2001. - 269 с.

6. Лаврищева Е. М. Методи программирования: теория, инженерия, практика / Е. М. Лаврищева. - К. : Наук. Дум- ка, 2006. - 452 c.

7. Глушков В. М. Кибернетика, вычислительная техника, информатика / В. М. Глушков. - К. : Наук. думка. - избранные труды в 3 - х тт., т. 3. - 1990. - 223 с.

8. Михалевич В. С. Концепция построения основных функциональных подсистем СППР / В. С. Михалевич, В. Л. Волкович // Автоматика. - 1993. - №> 3. - С. 3 - 13.

9. Михалев С. Б. Методологические основы разработки АСУ / С. Б. Михалев. - Минск: Высш. Шк, 1975. - 245 с.

10. Сергиенко И. В. Математические модели и методы решения задач дискретной оптимизации / И. В. Сергиенко. К. : Наук. думка, 1988. - 472 с.

11. Хакен Г. Синергетика / Г. Хакен. - М. : Мир, 1983. - 346 с. 12. Чернавский Д. С. Синергетика и информация / Д. С. Чернавский. - М. : Знание, 1990. - 48 с. 